\title{
Editorial: IZA Journal of European Labor Studies
}

\author{
Alan Barrett, Sara de la Rica, Martin Kahanec and Klaus F Zimmermann
}

Correspondence: izajoels@iza.org Editors of the IZA Journal of European Labor Studies
We are delighted to become the founding Editors of the IZA Journal of European Labor Studies, and to have the privilege to do so with a group of exceptional Associate Editors including Werner Eichhorst, Pawel Kaczmarczyk, Francis Kramarz, Jonathan Portes, Jo Ritzen, Nina Smith, Coen Teulings, Mirjam van Praag, Arthur van Soest, and Etienne Wasmer. The broad and in-depth expertise embodied in this Editorial Board ensures a rigorous selection process identifying articles fulfilling highest academic standards; but also a selection process that will identify the most innovative and policy relevant articles in all the fields covered by the Journal.

Our mission is to publish high-quality international research on a wide range of issues of relevance for labor markets in Europe and within its various countries. As we wish to make a concrete contribution to the European discourse about current labor issues, we will focus on policy-oriented applied research. We will in particular seek articles dealing with concrete policy problems, reforms, proposals or issues around which European policy discourse evolves.

We believe in the need for up-to-date analysis for informed policy discourse and evidence-based policy making. Our team will therefore strive to change the culture of the currently prevailing sluggish refereeing process in our discipline. In particular, while we unconditionally commit to highest academic standards, our objective is to cut the time from paper submission to its availability to wide audience to weeks rather than months or - way too often - years.

In this process we will rely on an efficient refereeing process and skillful Editorial Office. We have also committed to the policy of open access to articles published in our Journal, providing for quick access to a broad readership.

Above all, we will rely on you. We rely on you in your role of an author who follows the submission guidelines as closely as possible. We rely on you in your role of a reviewer, who values the reciprocal benefits of an efficient review process.

In turn, we will not waste your time and reward you with an expeditious review process. We will desk-reject papers that we believe bear little chance of passing through the full review process. We will provide our referees with review templates enabling an efficient referee review of high information value for the authors. As we value very highly all the genuine effort preceding your paper submission, in the whole process we will treat all the submitted work most respectfully and with great care, maintaining the highest standards of confidentiality.

We will then feel most privileged to disseminate your work among our distinguished readership and thus contributing to the science of Economics. We will feel especially honored by making your work known for informing and shaping the European labor

(c) 2012 Barrett et al.; licensee Springer. This is an Open Access article distributed under the terms of the Creative Commons Attribution License (http://creativecommons.org/licenses/by/2.0), which permits unrestricted use, distribution, and reproduction in any medium, provided the original work is properly cited. 
policy discourse. Please support our mission by submitting your best work to the IZA Journal of European Labor Studies.

Sincerely yours,

Alan Barrett

Sara de la Rica

\section{Editors}

Martin Kahanec

\section{Managing Editor}

Klaus F. Zimmermann

\section{Editor-in-chief for the Journal Series}

Received: 2 August 2012 Accepted: 2 August 2012

Published: 9 October 2012

doi:10.1186/2193-9012-1-1

Cite this article as: Barrett et al: Editorial: IZA Journal of European Labor Studies. IZA Journal of European Labor Studies 2012 1:1.

\section{Submit your manuscript to a SpringerOpen ${ }^{\circ}$ journal and benefit from:}

- Convenient online submission

- Rigorous peer review

- Immediate publication on acceptance

- Open access: articles freely available online

- High visibility within the field

- Retaining the copyright to your article

Submit your next manuscript at $\boldsymbol{\nabla}$ springeropen.com 